\title{
Editorial
}

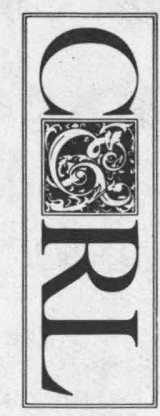

\section{From the Drawer: To the Wall}

"To Marta: From the Drawer" was the title of the September 1987 editorial in College $\mathcal{E}$ Research Libraries. Dissident Czech writers were discussed-how some felt compelled to put their work in the drawer, while others circulated their manuscripts to friends and colleagues. Knowledge of the circulated manuscripts increased and sometimes acquired a wide circle of readers. Occasionally their works appeared abroad. This is how I discovered a collection of short literary essays by Ludvik Vaculik.

In his introduction to these essays, Vaclav Havel, another well-known Czech writer, voiced concern that his country may have cut itself off from the rest of the world. He wondered if we would still be able to understand one another.

Directly, and forcefully, Havel partially answered his own question. Today he is President of Czechoslovakia. By struggling for and winning freedom, he and his countrymen reached out in a way that we can understand both symbolically and intuitively. The point of the editorial, however, was not focused on the attainment of freedom but on our experiences with and uses of freedom in daily life.

In his first essay, "Free to Use the Typewriter," Vaculik asks,

When did you last read anything interesting in the papers? By that I don't mean interesting reports about matters economic or technical, about natural phenomena or political revolutions, but an interesting idea on any of these subjects. You can progress along the road of discovery without anything really new being said until such time as someone gets a personal feeling about it and tries to put his thoughts into words.

The existence of interesting ideas in a culture is due to factors that lie much deeper than the popular conception of freedom implies. For example, are there societal or cultural constraints on our freedom of expression? Do we use our freedoms either individually or collectively to suppress new ideas, or the people who represent these new or divergent perspectives and experiences?

Some may think that these questions are not relevant to the issues faced in higher education because our "assumed" practice of noble ideals places us beyond reproach. Clark Kerr disagrees. This former president of the University of California finds no evidence that morality is at a higher level on campus than off campus. He is not alone.

Michael Skolnik reviews a body of literature in his article, "How Academic Program Reviews Can Foster Intellectual Conformity and Stifle Diversity of Thought and Method,' which raises serious issues about the openness of the university. The conclusions of four scholars are quoted here:

- Intolerance for new and different ideas, although it has no place in the university, is often found there (I. Winchester in a chapter to a book entitled, The Future of a Mediaeval Institution: The University in the Twenty-first Century).

- A major theme in biographies and autobiographies of scientists is the intolerance with which ideas are met and not infrequently suppressed (B. Barker in a chapter to a book entitled, The Sociology of Science). 
- The American university encourages publications largely for the sake of institutional prestige, rewarding mediocrity as often as merit, and exerting enormous pressure on dissident faculty to conform (T. Veblen, The Higher Learning in America).

- The critical, the controversial, and the imaginative are not allowed to see the light of day (D. Lindsey, The Scientific Publication System in Science).

If accurate, these findings are disturbing. They should lead us to be wary of societal, organizational, or group norms that restrict us from discussing issues openly. They should lead us to wonder about the negative effects of pressures to conform. Indeed, one side effect of the increased participation of employees in organizational decision making may be an increase in the tendency to reinforce the status quo and to coalesce against change. This force or influence may impede an organization's responsiveness to changing client needs or emerging opportunities.

Personally I am concerned about how pressures to conform may limit personal growth. Potentially strong and dynamic personalities may remain dormant. Affirmative, caring, or other life-giving values may be rejected. The creative force may be repressed.

Less than a week after the Berlin Wall opened in November, I took a very spontaneous trip to West Berlin in order to participate in events. I hammered and chiseled at the Wall. Many others joined together in this effort. While we can remove these obvious barriers, there are more subtle barriers that must be torn down before the ideals of freedom are achieved.

Some of us can cry with joy for what has been gained while reflecting in sadness on how far we have to go before understanding, tolerance, and freedom are achieved in their most profound sense.

\section{CHARLES MARTELL}

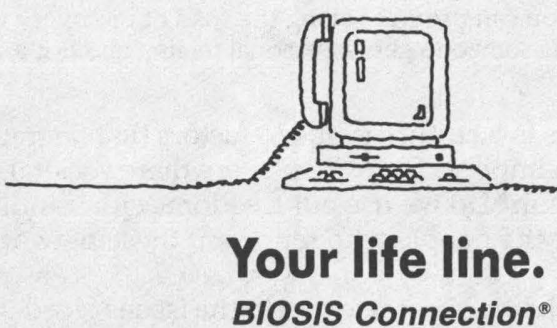

Keeping your finger on the pulse of biological and biomedical research information is as easy as pressing a button. The BIOSIS Connection is your low-cost direct line to the world's largest abstracting and indexing service for the life sciences, and you can be part of it!

This exciting and invaluable computerized information service connects you to all the research and professional information you need, with current awareness databases covering journal literature,

patents, books, meetings, theses, upcoming events and employment openings.

All it takes to extend your life line is a modem-equipped personal computer or terminal and a phone line. And what's more, you need no special search skills to use the BIOSIS Connection!

Put your fingers on the life line... Subscribe now to the BIOSIS Connection!

BIOSIS Connection is a registered trademark of BIOSIS.

For more information, a Sign-Up Kit, or a free demonstration disk, contact BIOSIS, 2100 Arch Street, Dept. CRL390LL, Philadelphia, PA 19103-1399 USA. Telephone (215) 587-4800 worldwide; toll free 1-800-523-4806 (USA except PA); Telex 831739; Fax (215) 587-2016. 


\section{ACQUISITION PERSPECTIVES}

2. Book House guarantees to order each book you request, with regular claiming to publishers. From major publishers on open account to the most obscure press requiring prepayment and offering no discount, our persistence and experience enables us to deliver every available title.

There is no substitute for complete delivery.

\section{- dNP BO0K IN PRNT}

COMPHith DHAVH?

TE: BXST VRLOT

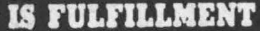

BOOK HOUSE
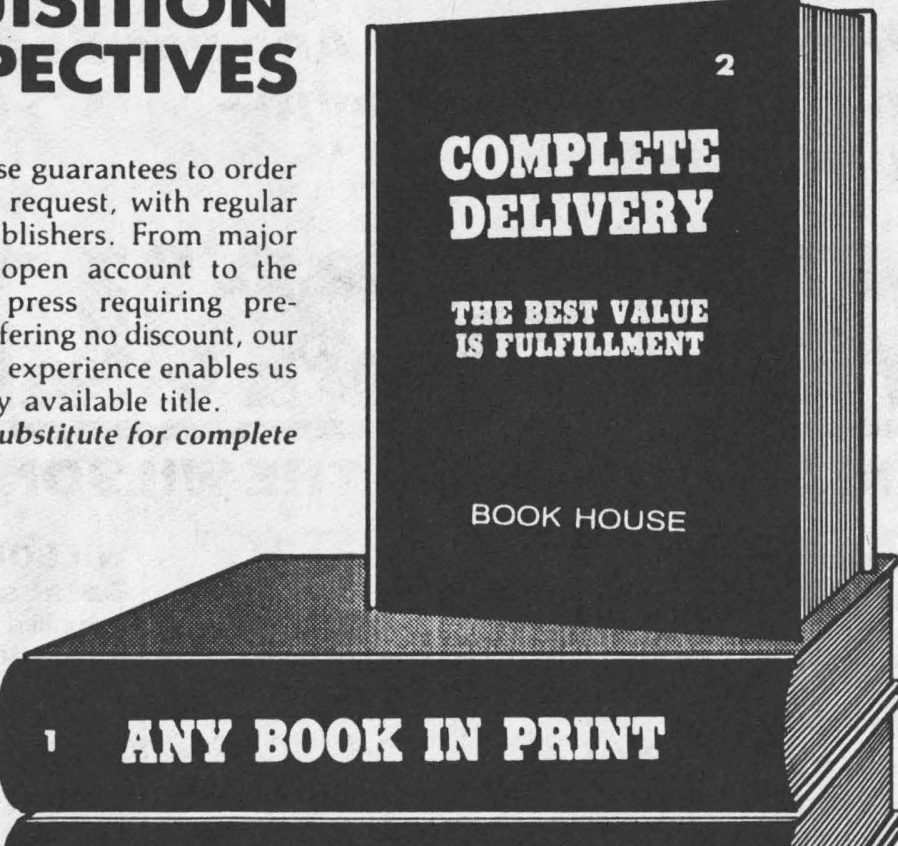

3 OPHA ORDAR RमPORIS

4 ACGULREH BOOE DHAWHI?

the

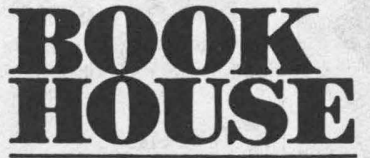
INC.

Since 1962

JOBBERS SERVING LIBRARIES WITH

ANY BOOK IN PRINT SINCE 1962

208 WEST CHICAGO STREET

JONESVILLE, MICHIGAN 49250.0125

\section{Call or Write TODAY}

$1 \cdot 800 \cdot 248 \cdot 1146$

FAX: $517 \cdot 849 \cdot 9716$ 


\section{When You Need an Answer Fast, and It Has to Be Right- Turn to}

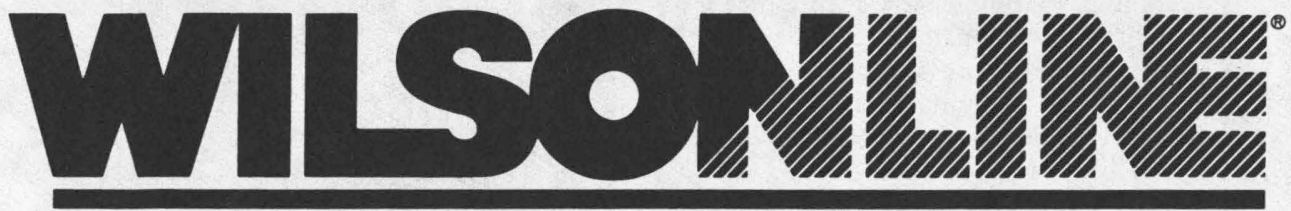

ONLINE ACCESS TO THE WILSON INDEXES

\section{"Recommended for all libraries." \\ - REFERENCE BOOKS BULLETIN}

\section{"A sophisticated search system that will impress search- ers accustomed to the most advanced techniques."}

-DATABASE

\section{Current \\ Bibliographic Data}

Indexing everything from popular magazines to professional journals, WILSONLINE covers:

More than half a million articles in nearly 4,000 periodicals each year

- 80,000 books annually

- 24,000 government publications annually

- More than 1 million new records each year

A total of more than 5 million records to date.

\section{Quality}

Updated at least twice each week, WILSONLINE databases contain the same dependable information as the familiar printed versions.

\section{Affordability}

WILSONLINE's pricing makes it affordable for more libraries than any comparable service. WILSONLINE becomes even more affordable when you add up the fees you don't have to pay: No start-up fee...

No charge for saved searches... No royalty charges added to connect-time rates.

\section{User-Friendly} WILSONLINE Features

Up to 43 different access points to bibliographic records - Nested Boolean logic • Proximity searching - Free text searching

- Automatic substitution of preferred form of subject headings and personal and corporate names • Controlled vocabulary searching $\bullet$ A toll-free number for user assistance $\bullet$ Online help command and explain messages - Searching of up to 8 databases simultaneously.

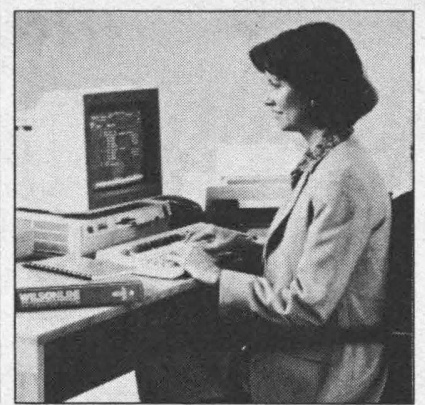

\section{WILSONLINE Databases}

- Applied Science \& Technology Index • Art Index • Bibliographic Index $\bullet$ Biography Index

- Biological \& Agricultural Index

- Book Review Digest - Business Periodicals Index $\bullet$ Cumulative Book Index - Education Index - Essay and General Literature Index • General Science Index - *GPO Monthly Catalog

- Humanities Index • Index to Legal Periodicals • *Index to U.S. Government Periodicals - *'LC/Foreign MARC File - * LC/MARC File - Library Literature * *MLA International Bibliography - Readers' Guide Abstracts • Readers' Guide to Periodical Literature $\bullet *^{*}$ Religion Indexes - Social Sciences Index - Vertical File Index • Wilson Journal Directory $\bullet$ Wilson Name Authority File - Wilson Publishers Directory

*Databases not produced by The H.W. Wilson Company.

TO OPEN YOUR WILSONLINE ACCOUNT CALL TOLL-FREE: 1-800-367-6770

In New York State, call 1-800-462-6060; in Canada, call collect 1-212-588-8400. Telefax 1-212-590-1617.

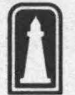

\section{THE \\ H.W. WILSON \\ COMPANY}

950 University Avenue

Bronx, New York 10452

(212) 588-8400

WILSONUINE IS A SERVICE MARK OF THE H.W. WILSON COMPANY. O1989 THE H.W. WILSON COMPANY. 